\title{
STUDY OF DAILY EXTREME TEMPERATURE INDICES OVER SUTLEJ BASIN, N-W HIMALAYAN REGION, INDIA
}

\author{
SINGH D. ${ }^{1}$ \\ GUPTA R.D. ${ }^{2, *}$ \\ JAIN S.K ${ }^{3}$
}

\author{
${ }^{1}$ CSIR NET (SRF), Department of GIS Cell \\ Motilal Nehru National Institute of Technology, Allahabad-211004, India \\ ${ }^{2}$ Department of Civil Engineering \\ Motilal Nehru National Institute of Technology \\ Allahabad-211004, Uttar Pradesh, India \\ ${ }^{3}$ Water Resources Systems Division, National Institute of Hydrology \\ Roorkee- 247667, India
}

Received: 30/09/2014

Accepted: 04/04/2015

Available online: 28/04/2015 *to whom all correspondence should be addressed: e-mail: gupta.rdg@gmail.com

\section{ABSTRACT}

A detailed analysis of extreme temperature indices for the period of 1970-2005 is conducted over Sutlej river basin located in North-West Himalayan region. For this purpose, daily records of maximum and minimum temperature data were procured from Bhakara Beas Management Board, India for four stations. These stations are installed at varying height from $518 \mathrm{~m}$ to $976 \mathrm{~m}$ under different physiographic and climatic conditions. Fourteen extreme indices for temperature as specified by the World Meteorological Organization (WMO) Commission for Climatology (CCL)/Climate Variability and Predictability (CLIVAR) Expert Team on Climate Change Detection, Monitoring and Indices (ETCCDMI) are derived with the aid of RClimDex software. Linear Regression (LR) method is employed for detecting annual as well as monthly trends in extreme indices of temperature over the period of thirty six years (1970-2005). Large spatial and inter-annual variability in trends of extreme indices is observed. However, a rise in diurnal temperature range is observed for the basin as a whole. This may be attributed to the decrease observed in maximum $T_{\text {Min }}$ (TXn) and warm nights (TN90p) coupled with the increase in maximum $T_{\operatorname{Max}}(T X x)$.

Keywords: Linear regression, trend, extreme temperature indices, Sutlej basin

\section{Introduction}

There is a general agreement that climate change, whether induced by natural or human forcings, can bring changes in the likelihood of the occurrence or strength of extreme weather and climate events (Cubasch et al., 2013). It is observed that slight change in frequency or intensity of extreme events (e.g., heat waves, floods and droughts) could bring significant impacts on both human society and natural environment (Easterling et al., 2000). During recent past, increase in number and magnitude of extreme weather/climate events is observed in most parts of the world causing huge loss of lives, extensive damages to crops, properties and immeasurable misery to millions of people (Hartmann et al., 2013). The Intergovernmental Panel on Climate Change (IPCC) in its Fourth Assessment Report (AR4) has shown concerns for extreme weather events as some types of weather extremes are anticipated to become more persistent in the future

Singh D., Gupta R.D. and Jain S.K. (2015), Study of daily extreme temperature indices over Sutlej Basin, N-W Himalayan Region, India, Global NEST Journal, 17(2), 301-311. 
(IPCC, 2007; Moberg et al., 2006). Globally, increased vulnerabilities of human society to such events have encouraged study of extreme weather events (Donat et al., 2013; Groisman et al., 2005).

The global scale studies conducted by researchers reported an overall increase in number of warm days, warm night and heat waves with decrease in the occurrence of cold days and cold nights (Alexander et al., 2006; Hartmann et al., 2013). Similar patterns are also observed in regional studies of extreme indices undertaken in different parts of the world. However, very few studies of extreme events are reported for African and Asian regions covering a broad range of countries, some of which have poor data availability, quality and consistency (Manton et al., 2001). Easterling et al., (2003), investigated trends in six extreme indices (four for temperature and two for precipitation) over Africa for 1961-1990. Their study displayed increase in number of warm days and warm night with consistent decrease in cold days and cold nights. A couple of studies, one by Manton et al., (2001), for South East Asia and South Pacific and another by Sheikh et al., (2014) for South Asia were undertaken for studying trends in extreme temperature and precipitation indices for the period of 1961-1998 and 1971-2000 respectively. Similarity in patterns of extreme indices were reported for these regions with increasing trends in annual number of warm days and warm night coupled with decreasing trends in annual number of cold days and cold nights.

In past, several studies on different spatial and temporal scales were carried out over India for studying trends and variability for various extreme indices of temperature (Kothawale et al., 2010; Panda et al., 2014). However, the research work carried out on temperature related extremes over the Himalayan region is not much which may primarily be contributed to the fact that this region is marked with sparse networks of meteorological stations and absence of relatively long-term consistent data sets. The mighty Himalaya along with El Nino/Southern Oscillation (ENSO) affects atmospheric circulation and exhibits significant control over the meteorological and hydrological conditions of Indian Sub-continent (Revadekar and Kulkarni, 2008). A minor shift in mean state of climate over the Himalaya has a potential to bring catastrophic consequences on the socio-economic survival of millions of people inhabiting the Indo-Gangetic plains.

Recent studies on Himalayan climate displayed significant changes in mean state of temperature during the twentieth century (Singh et al., 2015). The difference in patterns of low to medium intensity events at various stations established in Himalayan region was also reported by Joshi et al., (2014). Further, the regionalization of results in climatologically varied region like Himalaya may not give correct pattern of extreme events. This has encouraged research work leading to detailed analysis of extreme events in different isolated locations of the Himalaya. Therefore, more area specific studies over the Himalayan region are required for designing mitigation and adaptation measures to deal with these changes.

In line with the above, the present research work is undertaken to examine and detect trends in daily extreme indices of temperatures for selected stations located in Sutlej river basin, North-West Himalayan (NWH) region, India. For this purpose, 14 extreme indices as specified by the World Meteorological Organization (WMO) Commission for Climatology (CCL)/Climate Variability and Predictability (CLIVAR) Expert Team on Climate Change Detection, Monitoring and Indices (ETCCDMI) are derived from daily data of temperature (maximum and minimum) at individual stations for the period of 1970-2005. The detailed analysis for detecting annual as well as monthly trends in extreme indices of temperature over the period of thirty six years from 1970-2005 is performed using Linear Regression (LR) method.

\section{Data and methods}

\subsection{Study area}

The study is carried out over Indian part of Sutlej basin (up to Bhakara dam) having total surface area of $21078.6 \mathrm{~km}^{2}$ with highly variable topography having elevation range of 306 to $6752 \mathrm{~m}$. Geographically, the 
basin is locked up between latitudes from $31938^{\prime} 24^{\prime \prime} \mathrm{N}$ to $32{ }^{\circ} 18^{\prime} 36^{\prime \prime} \mathrm{N}$ and longitudes from 76일 $48^{\prime \prime} \mathrm{E}$ to 79000'00"E (Figure 1).

The large disparities in the topographical relief have resulted in variety of climate causing different types of flora and fauna in the Sutlej basin. Besides terrestrial flora and fauna, the Sutlej basin is very rich in aquatic life. The entire Sutlej river up to Govind Sagar reservoir and the tributaries of the river are home to 51 fish species belonging to 13 taxonomic families. The vegetation types in this region vary from Tropical to Alpine.

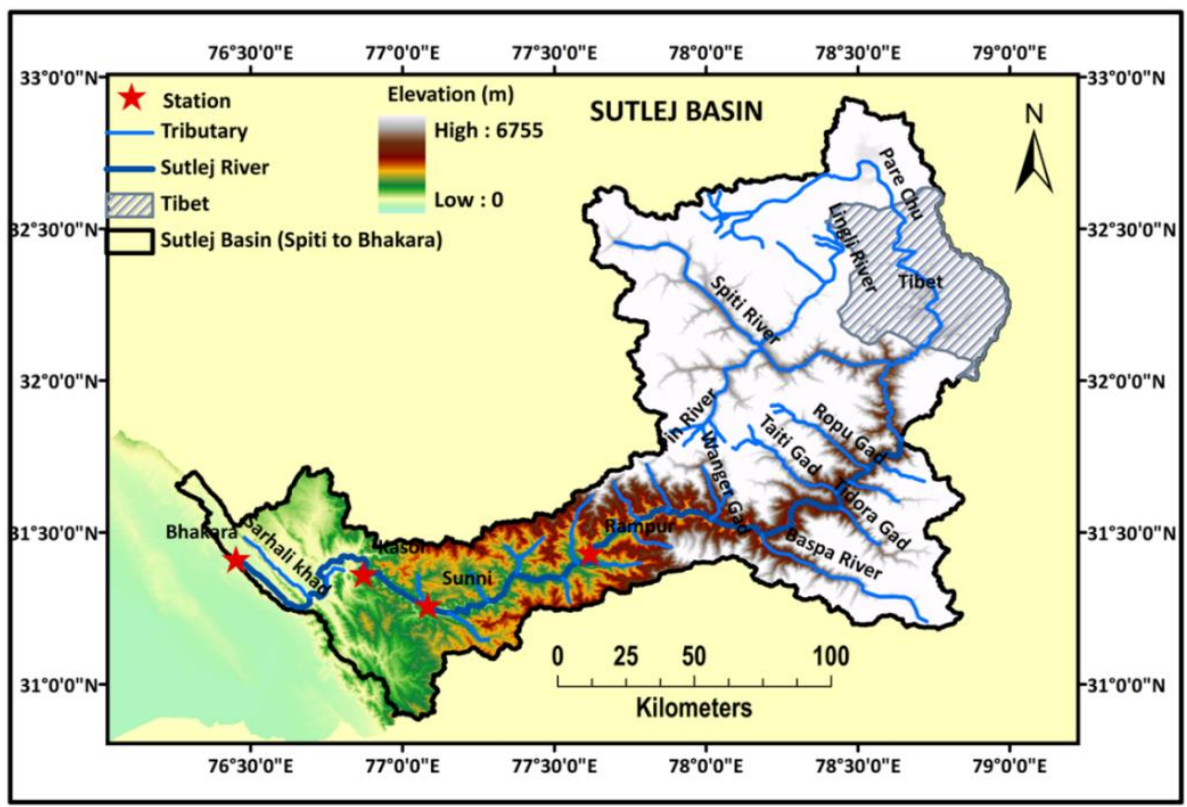

Figure 1. Location map of the study area

\subsection{Data and quality control}

Daily maximum and minimum temperature data from 1970-2005 are used for the analysis of extreme weather events over the study area. These data sets were procured from Bhakara Beas Management Board (BBMB), India. Only the stations having at least 360 days of data are included in the analysis. The raw data generally inherit inhomogeneities or discontinuities in the time series (Manton et al., 2001). The presence of erroneous outliers in time series may also impact the indices calculation and their trends (You et al., 2008). To remove these anomalies in the data, the daily time series of each station is first scrutinized visually to identify any obvious outliers, trends and potential discontinuities. Then, the procedure discussed by Kothawale et al., (2010) is adopted for screening of outliers from the time series. The inhomogeneities in the records are then tested using RHtestsV4 software (Marofi et al., 2011). If no major inhomogeneities are detected for a station, then it is allowed for analysis otherwise it is rejected. Based on the quality control and homogeneity test, data for a set of four stations, namely, Bhakara ( $518 \mathrm{~m}$ elevation), Kasol (662m elevation), Sunni (655m elevation), and Rampur ( $976 \mathrm{~m}$ elevation) are prepared for further analysis. The location of these four stations is marked in Figure1, as shown above.

\subsection{Methods}

\subsubsection{Indices and their derivation}

WMO-CCL/CLIVAR and ETCCDMI have approved 16 extreme indices for temperature (ETCCDI/CRD Climate Change Indices, 2014). The aim of the ETCCDMI is to determine a standardized set of indices allowing for uniformity in comparison across different regions. In the present study, only 14 extreme indices, excluding 
ice days (IDO) and growing season length (GSL), are further examined as these are found relevant to the study area. These 14 indices are shown in Table 1.

Table 1. List of ETCCDMI extreme temperature indices

\begin{tabular}{|c|c|c|c|}
\hline ID & Indicator name & Definitions & Units \\
\hline FDO & Frost days & Annual count when $\mathrm{TN}($ daily minimum $)<0 \circ \mathrm{C}$ & Days \\
\hline SU25 & Summer days & Annual count when $\mathrm{TX}$ (daily maximum) $>25 \circ \mathrm{C}$ & Days \\
\hline TR20 & Tropical nights & Annual count when TN(daily minimum) $>20^{\circ} \mathrm{C}$ & Days \\
\hline TXX & $\operatorname{Max} T_{\operatorname{Max}}$ & Monthly maximum value of daily maximum temp & ${ }^{\circ} \mathrm{C}$ \\
\hline $\mathrm{TNx}$ & $\operatorname{Max} T_{\operatorname{Min}}$ & Monthly maximum value of daily minimum temp & ${ }^{\circ} \mathrm{C}$ \\
\hline TXn & Min $\mathrm{T}_{\text {Max }}$ & Monthly minimum value of daily maximum temp & ${ }^{\circ} \mathrm{C}$ \\
\hline $\mathrm{TNn}$ & Min $T_{\operatorname{Min}}$ & Monthly minimum value of daily minimum temp & ${ }^{\circ} \mathrm{C}$ \\
\hline TN10p & Cool nights & Percentage of days when $\mathrm{TN}<10$ th percentile & Days \\
\hline TX10p & Cool days & Percentage of days when $\mathrm{TX}<10$ th percentile & Days \\
\hline TN90p & Warm nights & Percentage of days when $T N>90$ th percentile & Days \\
\hline TX90p & Warm days & Percentage of days when $T X>90$ th percentile & Days \\
\hline WSDI & $\begin{array}{l}\text { Warm spell duration } \\
\text { indicator }\end{array}$ & $\begin{array}{l}\text { Annual count of days with at least } 6 \text { consecutive } \\
\text { days when } T X>90 \text { th percentile }\end{array}$ & Days \\
\hline CSDI & $\begin{array}{l}\text { Cold spell duration } \\
\text { indicator }\end{array}$ & $\begin{array}{c}\text { Annual count of days with at least } 6 \text { consecutive } \\
\text { days when } \mathrm{TN}<10 \text { th percentile }\end{array}$ & Days \\
\hline DTR & $\begin{array}{c}\text { Diurnal temperature } \\
\text { range }\end{array}$ & Monthly mean difference between TX and TN & ${ }^{\circ} \mathrm{C}$ \\
\hline
\end{tabular}

The arbitrary thresholds as well as percentiles based methods are used in defining the extreme indices (Marofi et al., 2011). In this study, extreme indices for temperature are derived using RClimDex software which was developed and maintained by Zhang and Yang, (2004). All the fourteen indices are calculated on yearly time scale while nine indices (TXx, TNx, TXn, TNn, TN10p, TX10p, TN90p, TX90p, DTR) are calculated on monthly time scale also, both at $10 \%$ level of statistical significance.

\subsubsection{Trend analysis method}

Linear Regression (LR), a parametric statistical method, is used for trend analysis. LR method has been found to be more powerful than non-parametric test for the normally distributed variables (Helsel and Hirsch, 1992). LR method not only detects trend but also quantifies change in data over time.

In trend analysis, null hypothesis $\left(H_{0}\right)$ of no trend is checked with the alternative hypothesis $\left(H_{i}\right)$ of increasing or decreasing trend. For LR method, the response of a random variable $\mathrm{Y}$ (e.g. temperature) over time $\mathrm{t}$ is estimated from the equation (Helsel and Hirsch, 1992):

$$
Y=a t+b
$$

Where, $\mathrm{t}=$ time (year), $\mathrm{a}=$ slope/regression coefficient $\mathrm{and} \mathrm{b}=$ least-squares estimate of the intercept. The slope coefficient indicates the annual average rate of change in the variable $Y$. If the slope is significantly different from zero statistically, it is entirely reasonable to interpret that there is a real change occurring over time. The sign of the slope defines the direction of the trend of the variable; increasing if the sign is positive $(+)$ and decreasing if the sign is negative $(-)$. The null hypothesis $\left(H_{0}\right)$ of no trend is rejected when the test 
statistic $T$ value is greater than the critical value $T_{\alpha / 2}$ with a significance level $\alpha$. In this study, $H_{0}$ is tested at 5\% level of significance. According to Haan (1977), the test statistic T is defined as given below:

$T=\frac{r \sqrt{n-2}}{\sqrt{1-r^{2}}}=\frac{b}{s / \sqrt{S S x}}$

This follows Student's $t$ distribution with degrees of freedom $n-2$, where $n$ is sample size, $s$ is standard deviation of residuals, SSx is sums of squares of the independent variable (time in trend analysis) and $r$ is Pearson correlation coefficient (Onöz and Bayazit, 2003).

\section{Results and discussions}

After calculating 14 extreme indices of temperature, annual as well as monthly, wherever appropriate, trends in these indices are detected using LR method for Bhakara, Kasol, Sunni and Rampur stations of Sutlej river basin located at varying altitudes under different physiographic and climatic conditions. The trends are detected over the period of 1970-2005. The results obtained from trend analysis are presented under sections 3.1 and 3.2 respectively.

\subsection{Annual trends in extreme indices of temperature}

The results showing trends in annual extreme indices of temperature for the period of 1970-2005 are presented in Table 2. Large variations in trends of annual indices of temperature are perceived and it has varied spatially i.e. station wise. Statistically significant upward trend in numbers of cool nights (TN10p), cold spell duration (CSDI) and magnitude of maximum $T_{\operatorname{Max}}(T X X)$ and Diurnal Temperature Range (DTR) is detected at Bhakara. This is followed by statistically significant downward trends in tropical nights (TR20), warm nights (TN90p), maximum $T_{\operatorname{Min}}(T N x)$ and minimum $T_{M i n}(T N n)$ respectively. The remaining indices like summer days (SU25), warm spell duration indicator (WSDI) and warm days (TX90p) are also marked by positive trends, but the results are statistically insignificant in nature.

A complex pattern in extreme indices is observed at Kasol. The rise in number of cool days (statistically significant at $5 \%$ significance level), cold spell duration and DTR (statistically insignificant) are observed. On the other hand, statistically significant decreasing trends in number of tropical nights, warm nights, magnitude of min $\mathrm{T}_{\operatorname{Max}}$ and minimum $\mathrm{T}_{\text {Min }}$ including maximum $\mathrm{T}_{\text {Min }}$ (statistically insignificant) were detected. But, no particular trends could be perceived in number of summer days, cool nights, warm days and warm spell duration and in magnitude of maximum $\mathrm{T}_{\mathrm{Max}}$.

Only five indices showed statistically significant trends at Sunni. Out of these five, three (cool nights, DTR and maximum $\mathrm{T}_{\mathrm{Max}}$ ) showed upward trends while the others (tropical nights and warm nights) showed downward trend. In addition, statistically insignificant rising trends in number of frost days, cold spell duration and in amount of minimum $\mathrm{T}_{\mathrm{Max}}$ are detected. The other left behind indices of temperature i.e. summer days, maximum $T_{\text {Min, }}$, minimum $T_{\text {Min, }}$ warm days and warm spell duration exhibited no trend for the above period.

The annual trend analysis of extreme temperature indices performed over Rampur station indicated rise

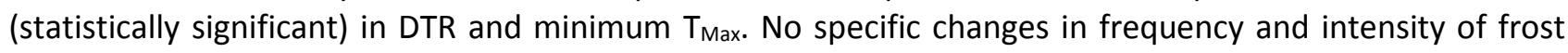
days, summer days, maximum $\mathrm{T}_{\mathrm{Min}}$, warm nights and duration of warm spell are identified during this period. The indices (cool nights and spell of cold duration) which had shown upward trend over Bhakara, Kasol and Sunni, revealed statistically insignificant downward trend at Rampur. 
Table 2. Annual trends in extreme temperature indices at different stations of Sutlej river basin over the period of 1970-2005 (at 5\% level of significance)

\begin{tabular}{|c|c|c|c|c|c|c|c|c|}
\hline \multirow{3}{*}{ Indices } & \multicolumn{8}{|c|}{ Station } \\
\hline & \multicolumn{2}{|r|}{ Bhakara } & \multicolumn{2}{|r|}{ Kasol } & \multicolumn{2}{|r|}{ Sunni } & \multicolumn{2}{|r|}{ Rampur } \\
\hline & Trend & $\begin{array}{c}\text { Rate of } \\
\text { change }\left({ }^{\circ} \mathrm{C} \text { or }\right. \\
\text { day/year })\end{array}$ & Trend & $\begin{array}{c}\text { Rate of } \\
\text { change }\left({ }^{\circ} \mathrm{C} \text { or }\right. \\
\text { day/year })\end{array}$ & Trend & $\begin{array}{c}\text { Rate of } \\
\text { change }\left({ }^{\circ} \mathrm{C}\right. \\
\text { or day/year })\end{array}$ & Trend & $\begin{array}{c}\text { Rate of } \\
\text { change }\left({ }^{\circ} \mathrm{C} \text { or }\right. \\
\text { day/year) }\end{array}$ \\
\hline FD0 & NA & NA & NA & NA & + & 0.55 & NT & \\
\hline SU25 & + & 0.37 & NT & & NT & & NT & \\
\hline TR20 & $-*$ & -0.66 & $-*$ & -0.67 & $-*$ & -0.66 & + & 0.19 \\
\hline TXX & $+*$ & 0.06 & NT & & $+*$ & 0.11 & + & 0.04 \\
\hline $\mathrm{TNx}$ & $-*$ & -0.05 & - & -0.03 & NT & & NT & \\
\hline TXn & NT & & $-*$ & -0.06 & + & 0.06 & $+*$ & 0.07 \\
\hline $\mathrm{TNn}$ & $-*$ & -0.08 & $-*$ & -0.03 & NT & & + & 0.02 \\
\hline TN10p & $+*$ & 0.34 & NT & & $+*$ & 0.20 & - & -0.11 \\
\hline TX10p & - & -0.15 & $+*$ & 0.13 & - & -0.07 & - & -0.08 \\
\hline TN90p & $-*$ & -0.31 & $-*$ & -0.18 & $-*$ & -0.32 & NT & \\
\hline TX90p & + & 0.12 & NT & & NT & & + & 0.2 \\
\hline WSDI & + & 0.02 & NT & & NT & & NT & \\
\hline CSDI & $+*$ & 0.61 & + & 0.06 & + & 0.18 & - & 0.24 \\
\hline DTR & $+*$ & 0.08 & + & 0.01 & $+*$ & 0.07 & $+*$ & 0.04 \\
\hline
\end{tabular}

(* indicates results are statistically significant at $5 \%$ level, NT stands for No Trend)

In general, annual trends observed in these extreme indices are not in line of previous studies conducted by taking India as a whole. Panda et al., (2014), examined trends in extreme indices of temperature over India using high resolution $\left(1^{\circ} \times 1^{\circ}\right)$ daily gridded data. Their studies indicate rise in hot extreme events (TXx, TX90p, TN90p, TNx, TR20, SU25 and WSDI) and decrease in cold extreme events (TX10p, TN10p, TXn, FD and CSDI) over the most part of the country for the period of 1971-2005. But, no such patterns in hot and cold extreme indices are observed for the study area as a whole. The observed trend pattern can be best explained by taking isolated stations because these are located at different altitudes with different climatic conditions as well as physiographic and environmental conditions.

\subsection{Monthly trends in extreme indices of temperature}

Monthly trends in maximum $T_{M a x}$, minimum $T_{M i n}$, minimum $T_{M a x}$, minimum $T_{M i n}$, cool nights, cool days, warm nights, warm days and diurnal temperature range are also computed for examining their inter-annual variability at different stations within the study area. The outcomes are discussed in the following subsections.

\subsubsection{Trends in extreme indices of temperature at Bhakara}

In general, increase in value of maximum $\mathrm{T}_{\mathrm{Max}}(\mathrm{TXX})$ are observed from January to September but it is more prominent during the months of April, May and June. The rest of the months of the year did not show any signal of change over time. Opposite to this, continuous decrease in value of maximum $T_{\min }(T N x)$ is perceived from January to November and results are statistically significant for the months of June, August, September, October and November. The minimum $\mathrm{T}_{\mathrm{Min}}(\mathrm{TNn})$ which is characterized either by decreasing or no trend has 
exhibited statistically significant trends during January, October, November and December. The same trend is also observed for warm nights (TN90p). All months of the year except September, October and November revealed statistically significant positive trends in DTR. The results obtained are compiled in Table 3. Similarly, positive trends are also detected in number of cool nights (TN10p) throughout the year except March and June.

Table 3. Monthly trends in extreme temperature indices at Bhakara over the period of $1970-2005$ (at $5 \%$ level of significance)

\begin{tabular}{|c|c|c|c|c|c|c|c|c|c|c|c|c|}
\hline \multirow{2}{*}{ Indices } & \multicolumn{12}{|c|}{ Month } \\
\hline & Jan & Feb & Mar & Apr & May & Jun & Jul & Aug & Sept & Oct & Nov & Dec \\
\hline TXX & + & + & NT & $+^{*}$ & $+*$ & $+^{*}$ & NT & + & + & NT & NT & NT \\
\hline TNx & - & NT & - & - & - & -* & - & -* & $-*$ & -* & $-*$ & NT \\
\hline TXn & NT & NT & NT & + & + & $+*$ & $*$ & + & NT & NT & NT & NT \\
\hline TNn & $-*$ & - & NT & - & - & NT & NT & - & NT & -* & -* & $-*$ \\
\hline TN10p & $+^{*}$ & + & NT & + & + & NT & + & + & + & $+^{*}$ & $+^{*}$ & $+*$ \\
\hline TX10p & NT & - & NT & NT & NT & - & - & - & - & NT & NT & NT \\
\hline TN90p & $-*$ & NT & NT & NT & - & - & -* & -* & $-*$ & $-*$ & - & - \\
\hline TX90p & NT & NT & NT & NT & + & $+*$ & NT & $+*$ & NT & NT & NT & NT \\
\hline DTR & $+^{*}$ & $+*$ & $+*$ & $+^{*}$ & $+*$ & $+^{*}$ & + & $+^{*}$ & + & + & + & $+^{*}$ \\
\hline
\end{tabular}

(* indicates results are statistically significant at $5 \%$ level, NT stands for No Trend)

\subsubsection{Trends in extreme indices of temperature at Kasol}

Trends derived for various extreme indices of temperature on monthly basis at Kasol are presented in Table 4. The results are intricate in nature. In most of the cases, increasing, decreasing or no trends are detected in extreme indices for different months of the year.

Table 4. Monthly trends in extreme temperature indices at Kasol over the period of $1970-2005$ (at 5\% level of significance)

\begin{tabular}{|c|c|c|c|c|c|c|c|c|c|c|c|c|}
\hline \multirow{2}{*}{ Indices } & \multicolumn{12}{|c|}{ Month } \\
\hline & Jan & Feb & Mar & Apr & May & Jun & Jul & Aug & Sept & Oct & Nov & Dec \\
\hline TXX & + & + & NT & + & + & NT & NT & NT & NT & NT & - & NT \\
\hline TNx & NT & NT & NT & NT & - & NT & -* & $-*$ & $-*$ & - & NT & NT \\
\hline$T X n$ & $-^{*}$ & $-*$ & NT & - & - & + & NT & $-*$ & - & $-^{*}$ & - & NT \\
\hline $\mathrm{TNn}$ & $-*$ & NT & NT & - & NT & NT & NT & NT & NT & $-*$ & NT & $-*$ \\
\hline TN10p & NT & + & NT & $+*$ & + & NT & - & NT & NT & NT & NT & + \\
\hline TX10p & $+^{*}$ & $+*$ & NT & $+*$ & NT & - & + & NT & + & $+^{*}$ & + & NT \\
\hline TN90p & NT & NT & NT & - & NT & NT & - & $-*$ & $-*$ & $-*$ & NT & NT \\
\hline TX90p & NT & NT & NT & NT & NT & NT & NT & NT & NT & - & NT & NT \\
\hline DTR & NT & NT & NT & + & + & + & NT & + & NT & NT & - & + \\
\hline
\end{tabular}

(* indicates results are statistically significant at $5 \%$ level, NT stands for No Trend) 
The maximum $T_{\operatorname{Max}}(T X x)$ which revealed rise in trend in initial moths of the year i.e. from January to May (with exception in March) is characterized by no trend in rest of the months of the year. Besides, increasing trends are also observed in cool nights (TN10p) during February, April, May, December months, then in cool days during January, February, April, July, September, October, November months, and also for DTR during April, May, June, August, December months respectively. Similarly, decreasing trends are detected in maximum $\mathrm{T}_{\mathrm{Min}}$ during May, July, August, September, October months, in minimum $\mathrm{T}_{\text {Max }}$ during January, February, April, May, August, September, October and November months, in minimum $\mathrm{T}_{\mathrm{Min}}$ during January, April, October, December months and in warm nights (TN90p) during April, July, August, September, October months respectively. However, all the indices of temperature showed no trend during March.

\subsubsection{Trends in extreme indices of temperature at Sunni}

At Sunni, increasing trends in maximum $T_{\operatorname{Max}}(T X x)$ are detected for April, May, June, July and August followed by decreasing trend in October and November. There is an increase in minimum $T_{\operatorname{Max}}(T X n)$ in January, June, July and December. The results of the trend observed are compiled in Table 5.

Table 5. Monthly trends in extreme temperature indices at Sunni over the period of $1970-2005$ (at 5\% level of significance)

\begin{tabular}{|c|c|c|c|c|c|c|c|c|c|c|c|c|}
\hline \multirow{2}{*}{ Indices } & \multicolumn{12}{|c|}{ Month } \\
\hline & Jan & Feb & Mar & Apr & May & Jun & Jul & Aug & Sept & Oct & Nov & Dec \\
\hline$T X x$ & NT & NT & NT & $+^{*}$ & $+^{*}$ & + & $+*$ & + & NT & - & - & NT \\
\hline TNx & -* & $-*$ & $-*$ & $-*$ & -* & - & NT & NT & NT & - & $-*$ & -* \\
\hline TXn & + & NT & NT & NT & NT & $+*$ & + & NT & NT & NT & NT & + \\
\hline $\mathrm{TNn}$ & NT & NT & - & $-*$ & -* & - & - & $-*$ & NT & - & - & NT \\
\hline TN10p & NT & NT & + & $+^{*}$ & + & + & + & + & NT & + & NT & NT \\
\hline TX10p & $-*$ & - & NT & NT & - & - & - & - & NT & NT & NT & NT \\
\hline TN90p & $-*$ & -* & -* & $-*$ & - & - & NT & NT & NT & $-*$ & $-*$ & $-*$ \\
\hline TX90p & NT & NT & NT & NT & NT & $+^{*}$ & + & NT & NT & NT & NT & NT \\
\hline DTR & + & $+^{*}$ & + & + & $+*$ & $+^{*}$ & $+^{*}$ & $+^{*}$ & NT & + & + & + \\
\hline
\end{tabular}

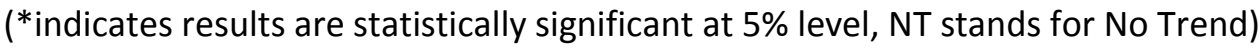

All months of the year with the exception of September have experienced rise in DTR. No trend is found in all indices of temperature during September. In addition, increase is also detected in the number of cool nights (March, April, May, June, July, August and October) and warm days (June and July). However, decrease in frequency of cool days (TX10p) is spotted in January, February, May, June, July and August and in warm nights (TN90p) throughout the year excluding July, August and September. The downward trends are also identified in maximum $\mathrm{T}_{\text {Min }}(\mathrm{TNx})$ during January, February, March, April, May, June, October, November, December months and in minimum $\mathrm{T}_{\mathrm{Min}}$ (TNn) during March, April, May, June, July, August, October, November months respectively.

\subsubsection{Trends in extreme indices of temperature at Rampur}

The results of monthly trends observed in extreme indices of temperature at Rampur are summarized in Table 6.

The trends are variable in nature over time i.e. changes from month to month. Rise in trend of maximum $T_{\operatorname{Max}}$ (TXX) is found in months of January, April, May, July, August, September, November and December. Additionally, increase is also observed in minimum $\mathrm{T}_{\text {Min }}$ (January, March, May and July), maximum $\mathrm{T}_{\text {Min }}$ (July 
and September), maximum $\mathrm{T}_{\text {Min }}$ (March and July), cool days (April and November), warm nights (March, July August and September), warm days (January, February, March, July, August, September, October and December) and in DTR (January, February, March, April, May, June, July and December). However, decreasing trends are perceived in maximum $\mathrm{T}_{\text {Min }}$ during January, April, May, June and in cool days during January, March, May, September, October and December respectively.

Table 6. Monthly trends in extreme temperature indices at Rampur over the period of $1970-2005$ (at $5 \%$ level of significance)

\begin{tabular}{|c|c|c|c|c|c|c|c|c|c|c|c|c|}
\hline \multirow{2}{*}{ Indices } & \multicolumn{12}{|c|}{ Month } \\
\hline & Jan & Feb & Mar & Apr & May & Jun & Jul & Aug & Sept & Oct & Nov & Dec \\
\hline TXX & $+*$ & NT & NT & + & + & NT & + & + & $+^{*}$ & NT & + & $+^{*}$ \\
\hline TNx & - & NT & NT & - & - & - & $+*$ & NT & $+^{*}$ & NT & NT & NT \\
\hline TXn & $+*$ & NT & + & NT & + & NT & $+*$ & NT & NT & NT & NT & NT \\
\hline TNn & NT & NT & + & NT & NT & NT & + & NT & NT & NT & NT & NT \\
\hline TN10p & NT & NT & NT & NT & NT & NT & - & NT & NT & NT & NT & NT \\
\hline TX10p & - & NT & - & + & - & NT & NT & NT & - & - & + & $-*$ \\
\hline TN90p & NT & NT & + & - & NT & - & $+*$ & + & + & NT & NT & - \\
\hline TX90p & $+*$ & + & + & NT & NT & NT & $+*$ & + & + & + & NT & $+^{*}$ \\
\hline DTR & $+^{*}$ & + & + & + & + & + & + & NT & NT & $\mathrm{NT}$ & NT & $+^{*}$ \\
\hline
\end{tabular}

(*indicates results are statistically significant at $5 \%$ level, NT stands for No Trend)

\section{Conclusions}

In the present study, annual as well as monthly trends in extreme indices of temperature are investigated in Sutlej river basin over the period of 36 years from 1970 to 2005. Three stations, namely, Kasol, Sunni and Rampur, in general, have shown either decrease or no change in hot extreme events (i.e. TXx, TX90p, TN90p, TNx, TR20, SU25 and WSDI). Opposite to this, some indicators of hot extreme events i.e. maximum $T_{\operatorname{Max}}$ (TXx), warm days (TX90p), summer days (SU25) and duration of wet spell (WSD) showed rising trend at Bhakara. This may be attributed to the changed land use patterns and increased human activities in the vicinity of Bhakra station, and it has more of plains like climate.

Further, rise in cold extreme events (TX10p, TN10p, TXn, FD and CSDI) are observed at Sunni excluding number of cool days. The rest of stations have mixed pattern in the trends of cold extreme events. In addition, the basin as a whole has experienced increase in DTR. This is thought to be linked with decrease observed in maximum $T_{\text {Min }}$ as well as in warm nights (TN90p) and increase in maximum $T_{\text {Max }}$ (TXX) respectively.

The disparities observed in pattern of extreme indices over different stations in Sutlej basin (Himalayan region) reflect difficulty in regionalization of results. This is mainly due to large variations in topography as well as in climate of the region. Therefore, more localized studies are needed for the NWH region. The present study is a step forwards in this direction to analyse the extreme temperature indices for four stations located at different elevations and under different physiographic and climatic conditions. There is a further need to increase and strengthen the network of stations in NWH region. Changes observed in extreme events in the basin may have serious implications on water resources and ultimately over ecological resources (flora and fauna) as their growth is highly affected by extreme temperature indices. Therefore, more studies examining water as well ecological resources are essential in future. 


\section{References}

Alexander L.V., Zhang X., Peterson T.C., Caesar J., Gleason B., Klein-Tank A.M.G., Haylock M., Collinset D., Trewin B., Rahimzadeh F., Tagipour A., Rupa Kumar K., Revadekar J., Griffiths G., Vincent L., Stephenson D.B., Burn J., Aguilar E., Brunet M., Taylor M., New M., Zhai P., Rusticucci M. and Vazquez-Aguirre J.L. (2006), Global observed changes in daily climate extremes of temperature and precipitation, Journal of Geophysical Research-Atmospheres, 111, D05109, doi: 10.1029/2005JD006290.

Cubasch U., Wuebbles D., Chen D., Facchini M.C., Frame D., Mahowald N. and Winther J.G. (2013), Introduction. In: Climate Change 2013: The Physical Science Basis. Contribution of Working Group I to the Fifth Assessment Report of the Intergovernmental Panel on Climate Change, Stocker, T.F. et al., (Eds.), Cambridge University Press, Cambridge, United Kingdom and New York, NY, USA.

Donat M.G., Alexander L.V., Yang H., Durre I., Vose R., Dunn R.J.H., Willett K.M., Aguilar E., Brunet M., Caesar J., Hewitson B., Jack C., Klein Tank A.M.G., Kruger A.C., Marengo J., Peterson T.C., Renom M., Oria Rojas C., Rusticucci M., Salinger J., Elrayah A.S., Sekele S.S., Srivastava A.K., Trewin B., Villarroel C., Vincent L.A., Zhai P., Zhang X. and Kitching S. (2013), Updated analyses of temperature and precipitation extreme indices since the beginning of the twentieth century: The HadEX2 dataset, Journal of Geophysical Research: Atmosphere, 118, 2098-2118.

Easterling D.R., Alexander L.V., Mokssit A. and Detemmerman V. (2003), CCI/CLIVAR Workshop to Develop Priority Climate Indices, Bulletin of American Meteorological Society, 84, 1403-1407.

Easterling D.R., Meehl G.A., Parmesan C., Changnon S.A., Karl T.R. and Mearns L.O. (2000), Climate Extremes: Observations, Modeling, and Impacts, Science, 289(5487), 2068-2074, doi: 10.1126/science.289.5487.2068.

ETCCDI/CRD Climate Change Indices (2014) available at http://etccdi.pacificclimate.org/index.shtml. (Accessed on 4.07.2014).

Groisman P.Y., Knight R.W., Easterling D.R., Karl T.R., Hegerl G.C. and Razuvaev V.N. (2005), Trends in intense precipitation in the climate record, Journal of Climate, 18, 1326-1350.

Haan C.T. (1977), Statistical Methods in Hydrology, The lowa State University Press, Ames, USA.

Hartmann D.L., Klein Tank A.M.G., Rusticucci M., Alexander L., Brönnimann S., Charabi Y., Dentener F., Dlugokencky E., Easterling D., Kaplan A., Soden B., Thorne P., Wild M. and Zhai P.M. (2013), Observations: Atmosphere and Surface Supplementary Material, In: Climate Change 2013: The Physical Science Basis. Contribution of Working Group I to the Fifth Assessment Report of the Intergovernmental Panel on Climate Change, Stocker T.F. et al., (Eds.) available on www.climatechange2013.org and www.ipcc.ch. (Accessed on 10.08.2014).

Helsel D.R. and Hirsch R.M. (1992), Statistical Methods in Water Resources, Elsevier, 522.

Intergovernmental Panel on Climate Change (IPCC) (2007), Climate change (2007), Impacts, adaptation and vulnerability. Contribution of working group II to the Fourth Assessment Report of the Intergovernmental Panel on Climate Change, edited by M. Parry et al., Cambridge University Press, UK.

Joshi S., Kumar K., Joshi V. and Pande B. (2014), Rainfall variability and indices of extreme rainfall analysis and perception study for two stations over Central Himalaya, India, Natural Hazards, 72, 361-374, doi 10.1007/s11069-013-10124.

Kothawale D.R., Munot A.A and Krishna K.K. (2010), Surface air temperature variability over India during 1901-2007, and its association with ENSO, Climate Research, 42, 89-104, doi: 10.3354/cr00857.

Manton M.J., Della-Marta P.M., Haylock M.R., Hennessy K.J., Nicholls N., Chambers L.E., Collins D.A., Daw G., Finet A., Gunawan D., Inape K., Isobe H., Kestin T.S., Lefale P., Leyu C.H., Lwin T., Maitrepierre L., Ouprasitwong N., Page C.M., Pahalad J., Plummer N., Salinger M.J., Suppiah R., Tran V.L., Trewin B., Tibig I. and Yee D. (2001), Trends in extreme daily rainfall and temperature in Southeast Asia and the South Pacific: 1961-1998, International Journal of Climatology, 21,269-284.

Marofi S., Sohrabi M.M., Mohammadi K., Sabziparvar A.A. and Abyaneh H.Z. (2011), Investigation of meteorological extreme events over coastal regions of Iran, Theoretical and Applied Climatology, 103, 401-412, doi 10.1007/s00704-010-0298-3. 
Moberg A., Jones P.D., Lister D., Walther A., Brunet M., Jacobeit J., Alexander L.V., Della-Marta P.M., Luterbacher J., Yiou P., Chen D., Klein Tank A.M.G., Saladié O., Sigro J., Aguilar E., Alexandersson H., Almarza C., Auer I., Barriendos M., Begert M., Bergström H., Böhm R., Butler C.J., Caesar J., Drebs A., Founda D., Gerstengarbe F.W., Micela G., Maugeri M., Österle H., Pandzic K., Petrakis M., Srnec L., Tolasz R., Tuomenvirta H., Werner P.C., Linderholm H., Philipp A., Wanner H. and Xoplaki E. (2006), Indices for daily temperature and precipitation extremes in Europe analyzed for the period 1901-2000, Journal of Geophysical Research, 111, D22106, doi:10.1029/2006JD007103

Onöz B. and Bayazit M. (2003), The Power of Statistical Tests for Trend Detection, Turkish Journal of Engineering and Environmental Sciences, 27, 247-251.

Panda D.K., Mishra A., Kumar A., Mandal K.G., Thakur A.K. and Srivastava R.C. (2014), Spatiotemporal patterns in the mean and extreme temperature indices of India, 1971-2005, International Journal of Climatology, 34(13), 3585-3603, doi: 10.1002/joc.3931.

Revadekar J.V. and Kulkarni A. (2008), The El Nino-Southern Oscillation and winter precipitation extremes over India, International Journal of Climatology, 28, 1445-1452, doi: 10.1002/joc.1639.

Sheikh M.M., Manzoor N., Ashraf J., Adnan M., Collins D., Hameed S., Manton M.J., Ahmed A.U., Baidya S.K., Borgaonkar H.P., Islam N., Jayasinghearachchi D., Kothawale D.R., Premalal K.H.M.S., Revadekar J.V. and Shrestha M.L. (2014), Trends in extreme daily rainfall and temperature indices over South Asia, International Journal of Climatology, doi: 10.1002/joc.4081.

Singh D., Gupta R.D. and Jain S.K. (2015), Statistical Analysis of Long Term Spatial and Temporal Trends of Temperature Parameters over Sutlej River Basin, India, Journal of Earth System Science, 124(1), 17-35, doi:10.1007/s12040-0140530-0. .

You Q., Kang S., Aguilar E. and Yan Y. (2008), Changes in daily climate extremes in the eastern and central Tibetan Plateau during 1961-2005, Journal of Geophysical Research, 113, D07101, doi:10.1029/2007JD009389.

Zhang Xu. and Yang F. (2004), RclimDex user manual, available at http://etccdi.pacificclimate.org/software.shtml (Accessed on 14.04.2014). 